\title{
Characterization and source identification of a fine particle episode in Finland
}

Niemi, J. V.

Elsevier Ltd.

2004

Niemi, J.V. et al. 2004. Characterization and source identification of a fine particle episode in pÿFinland. Atmospheric Environment 38: 50035012

http://hdl.handle.net/1975/248

Downloaded from Helda, University of Helsinki institutional repository.

This is an electronic reprint of the original article.

This reprint may differ from the original in pagination and typographic detail.

Please cite the original version. 


\title{
Characterization and source identification of a fine particle episode in Finland
}

\author{
Jarkko V. Niemi ${ }^{\text {a,b,* }}$, Heikki Tervahattu ${ }^{\text {b,c }}$, Hanna Vehkamäki ${ }^{\text {, }}$, \\ Markku Kulmala $^{\mathrm{d}}$, Tarja Koskentalo ${ }^{\mathrm{e}}$, Markus Sillanpää ${ }^{\mathrm{f}}$, Minna Rantamäki ${ }^{\mathrm{f}}$ \\ ${ }^{a}$ Department of Biological and Environmental Sciences, University of Helsinki, P.O. Box 27, FIN-00014 Helsinki, Finland \\ ${ }^{\mathrm{b}}$ Nordic Envicon Ltd., Koetilantie 3, FIN-00790 Helsinki, Finland \\ ${ }^{\mathrm{c}}$ Cooperative Institute for Research in Environmental Sciences, University of Colorado, Campus Box 216, Boulder, CO 80309, USA \\ ${ }^{\mathrm{d}}$ Department of Physical Sciences, University of Helsinki, P.O. Box 64, FIN-00014 Helsinki, Finland \\ ${ }^{\mathrm{e}}$ Helsinki Metropolitan Area Council (YTV), Opastinsilta 6 A, FIN-00520 Helsinki, Finland \\ ${ }^{\mathrm{f}}$ Finnish Meteorological Institute, Sahaajankatu 20 E, FIN-00810 Helsinki, Finland
}

Received 16 January 2004; received in revised form 4 June 2004; accepted 17 June 2004

\begin{abstract}
A strong long-range transported (LRT) fine particle $\left(\mathrm{PM}_{2.5}\right)$ episode occurred from March 17-22, 2002 over large areas of Finland. Most of the LRT particle mass was in the submicrometre size fraction. The number of concentrations of 90-500 nm particles increased by a factor of 5.6 during the episode, but the concentrations of particles smaller than $90 \mathrm{~nm}$ decreased. This reduction of the smallest particles was caused by suppressed gas-to-particle conversion due to the vapour uptake of LRT particles. Individual particle analyses using SEM/EDX showed that the proportion of sulphurrich particles rose strongly during the episode and that the relative weight percentage of potassium was unusually high in these particles. The median $\mathrm{S} / \mathrm{K}$ ratios of S-rich particles were 2.1 at the beginning of the episode, 5.2 at the peak stage of the episode and 8.9 during the reference days. The high proportion of $\mathrm{K}$ is a clear indication of emissions from biomass burning, because $\mathrm{K}$ is a good tracer of biomass-burning aerosols. Trajectories and satellite detections of fire areas indicated that the main source of biomass-burning aerosols was large-scale agricultural field burning in the Baltic countries, Belarus, Ukraine and Russia. The higher S/K ratio of S-rich particles during the peak stage was obviously due to the increased proportion of fossil fuel-burning emissions in the LRT particle mass, since air masses arrived from the more polluted areas of Europe at that time. The concentrations of sulphate, total nitrate and total ammonium increased during the episode. Our results suggest that large-scale agricultural field burning may substantially affect $\mathrm{PM}_{2.5}$ concentrations under unfavourable meteorological conditions even at distances over $1000 \mathrm{~km}$ from the burning areas.
\end{abstract}

(C) 2004 Elsevier Ltd. All rights reserved.

Keywords: Aerosol particles; Long-range transport; Size distributions; Chemical composition; Sources

\footnotetext{
*Corresponding author. Department of Biological and Environmental Sciences, University of Helsinki, P.O. Box 27, FIN-00014 Helsinki, Finland. Tel.: + 358-9-19158841; fax: $+358-9-19158462$.

E-mail address: jarkko.v.niemi@helsinki.fi (J.V. Niemi).
}

\section{Introduction}

Fine aerosol particles $\left(\mathrm{PM}_{2.5}\right)$ may be transported over long distances and carry pollutants to remote areas, due to the slow rate at which these particles are removed 
from the atmosphere in the absence of precipitation. Long-range transport (LRT) of aerosols may have a substantial effect on $\mathrm{PM}_{2.5}$ concentrations that is associated with serious health problems (Dockery and Pope, 1994; Laden et al., 2000; Pope et al., 2002; WHO, 2002). The biological mechanisms behind the health effects are not yet well understood, but the high mass concentrations of fine particles and number concentration of ultrafine particles $\left(\mathrm{PM}_{0.1}\right)$ are suspected to be the most detrimental to health (WHO, 2003). No safe threshold concentration has been found below which ambient particulate matter has no effect on health (WHO, 2003).

The main sources of $\mathbf{P M}_{2.5}$ mass are primary emissions from combustion sources and secondary formation of particles from their precursor gases in the atmosphere (Kiehl and Rodhe, 1995). The local emissions of fine particle mass or their precursor gases are generally quite low in Finland (EMEP, 2001, 2002). Even in the urban areas of Helsinki, $50-70 \%$ of $\mathrm{PM}_{2.5}$ is LRT (Karppinen et al., 2004; Vallius et al., 2003). Mass concentrations of $\mathrm{PM}_{2.5}$ are low in Finland compared to their levels in polluted areas of central and Southern Europe (Ruuskanen et al., 2001; EMEP, 2002). The mean $\mathrm{PM}_{2.5}$ concentrations in 1999-2001 were only $9.6 \mu \mathrm{g} \mathrm{m}^{-3}$ at an urban monitoring station in Helsinki and $5.8 \mu \mathrm{g} \mathrm{m}^{-3}$ at a rural background station in Hyytiälä (Laakso et al., 2003). However, $\mathrm{PM}_{2.5}$ concentrations rise to high levels several times every year in Finland due to the LRT of particles (Niemi et al., 2002; Tervahattu et al., 2002).

The concentrations, compositions and sources of the different size fractions of aerosol particles in Finland have been examined in many recent studies (e.g. Kerminen et al., 2000, Pakkanen et al., 2001a, b; Laakso et al., 2003; Vallius et al., 2003), but despite this, quite little is known of LRT episodes. In the present article we describe an LRT episode that occurred in Finland on March 17-22, 2002. We studied the mass and number concentrations of PM as well as its chemical composition, using bulk and individual particle methods. Backward trajectories, Web Fire Maps and other emission source data were also used to identify the origins of the LRT emissions.

\section{Materials and methods}

\subsection{Meteorological and emission data}

The meteorological conditions during the episode were observed using meteorological analysis charts made by the Finnish Meteorological Institute and meteorological data collected by the Helsinki Metropolitan Area Council. Backward trajectories were produced using the vertical motion model in the HYSPLIT4
(HYbrid Single-Particle Lagrangian Integrated Trajectory) model (Draxler and Rolph, 2003). For detection of field fires, we used Web Fire Mapper (http://maps.geog.umd.edu), which is part of the moderate-resolution imaging spectroradiometer (MODIS) rapid response system (Justice et al., 2002). Using data in the European Monitoring and Evaluation Programme (EMEP), we searched for information on trace gas emissions of areas along the air mass routes (EMEP, 2001).

\subsection{Particle mass and number size distributions}

Particle mass and number size distributions were measured at a rural background station in Hyytiälä (Vesala et al., 1998) by the University of Helsinki (Department of Physical Sciences). The locations of Hyytiälä and other measurement sites used in this study are shown in Fig. 1. The particle mass fractions were measured with a Dekati PM-10 3-stage impactor with a backup filter. The duration of sample collection was $2-3$ days. The cut-off diameters $\left(D_{50}\right)$ of the impactor stages were $10,2.5$ and $1 \mu \mathrm{m}$. The materials of collection substrates, smearing of substrates to prevent particles from bouncing back from the substrates, and the gravimetric analysis are described in detail by Laakso et al. (2003).

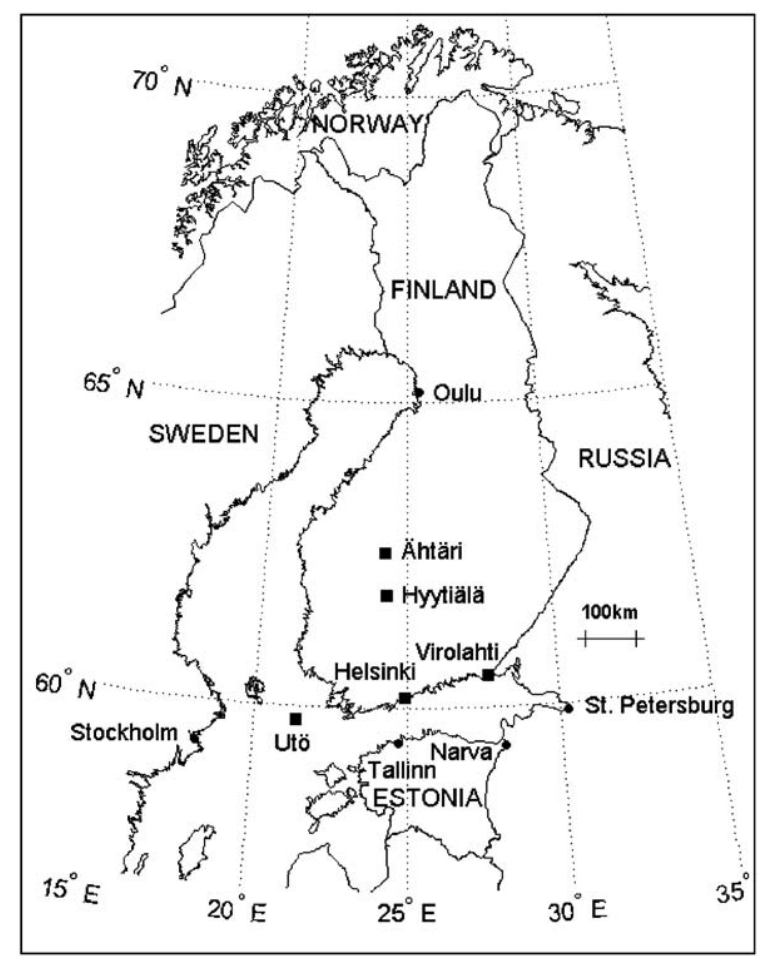

Fig. 1. Locations of the measurement sites (marked with squares). 
Particle number distributions were measured in the size range between 3 and $500 \mathrm{~nm}$, and the time resolution was $10 \mathrm{~min}$. The measurements were performed with a twin differential mobility particle sizer (DMPS). Small particles with diameter less than about $20 \mathrm{~nm}$ were measured with a TSI3021 condensation particle counter (CPC) and Hauke-type differential mobility analyser (DMA), whereas larger particles with a TSI3010 CPC and Hauke-type DMA.

\subsection{Ion analyses}

Rural background air quality is monitored at several measurement stations in Finland by the Finnish Meteorological Institute (FMI). We present ion measurement results from the EMEP stations in Ähtäri, Virolahti and Utö. Daily total suspended particle (TSP) samples were collected using open-faced 2-stage filter packs (NILU Products AS) containing cellulose filters (Whatman 40 , diameter $47 \mathrm{~mm})$. Sulphate $\left(\mathrm{SO}_{4}^{2-}\right)$, total nitrate $\left(\mathrm{NO}_{3}^{-}+\mathrm{HNO}_{3}(\mathrm{~g})\right)$, and total ammonium $\left(\mathrm{NH}_{4}^{+}\right.$ $\left.+\mathrm{NH}_{3}(\mathrm{~g})\right)$ were analysed with ion chromatography (IC, Waters). The details of the sampling and IC methods were described in Paatero et al. (2001).

\subsection{Individual particle analyses by $S E M / E D X$}

Air quality is monitored by the Helsinki Metropolitan Area Council at several measurement stations in the Helsinki metropolitan area. We selected particle samples for individual particle analyses collected at Vallila (an urban traffic station), Kallio (an urban background station) and Luukki (a rural background station). Particle samples were collected with Eberline FH 62 I$\mathrm{R}$ samplers (Eberline Instruments), which are based on $\beta$-attenuation. In all, 12 particle samples $\left(9 \mathrm{PM}_{2.5}\right.$ and 3 $\mathrm{PM}_{10}$ samples), collected during the episode and reference days, were selected for the analyses.

The elemental compositions of individual particles and agglomerates were studied with a scanning electron microscope (SEM-ZEISS DSM 962) coupled with an energy-dispersive X-ray microanalyser (EDX-LINK ISIS with the ZAF-4 measurement program). The SEM/EDX samples were prepared by pressing a tape (Scotch Ruban Adhesive) attached to an aluminium plate onto the filter surface covered with particles. The samples were then coated with carbon (Agar SEM Carbon Coater) to make the sample surfaces conductive. The accelerating voltage of the SEM was $20 \mathrm{kV}$ and counting time for the X-ray spectra was $15 \mathrm{~s}$.

The elemental compositions of 100 randomly selected particles or agglomerates (minimum diameter $1 \mu \mathrm{m}$ ) were analysed from each sample. The elemental weight percentages were calculated using ZAF-4 corrections for the following elements: $\mathrm{Na}, \mathrm{Mg}, \mathrm{Al}, \mathrm{Si}, \mathrm{S}, \mathrm{Cl}, \mathrm{K}, \mathrm{Ca}, \mathrm{Ti}$ and Fe. The ZAF-correction method is ideal for flat, homogenous samples, whereas particles of highly variable sizes and shapes reduce the accuracy of ZAFcorrected elemental results. This problem has been discussed in many articles, and the conclusion is that the accuracy of elemental analysis is sufficient to identify various particle types and to compare differences in elemental ratios of the same particle type in various samples (Gao and Anderson, 2001; Breed et al., 2002; Paoletti et al., 2002; Kupiainen et al., 2003).

\section{Results and discussion}

\subsection{General description of the LRT episode}

Fig. 2 shows the $\mathrm{PM}_{10}$ and $\mathrm{PM}_{2.5}$ concentrations in Helsinki during the episode on March 17-22, 2002. The episode was observed over a wide area, including as far north as Oulu, $600 \mathrm{~km}$ from Helsinki. PM concentrations rose simultaneously at all measurement stations of each town, while $\mathrm{NO}_{2}$ and $\mathrm{SO}_{2}$ concentrations remained nearly at their usual levels, indicating that the source of PM was not local traffic or industry. The maximum hourly $\mathrm{PM}_{10}$ means in the southern towns were about $80-90 \mu \mathrm{g} \mathrm{m}^{-3}$ and in the northern towns clearly lower. Most of the particle mass was in the $\mathrm{PM}_{2.5}$ size range, and the $\mathrm{PM}_{2.5}$ values were extraordinarily high. For example, the highest daily $\mathrm{PM}_{2.5}$ value during the episode at the Kallio urban background station in Helsinki was $42.5 \mu_{\mathrm{g} \mathrm{m}^{-3}}$, whereas the annual mean during 1999-2001 was only $8.2 \mu \mathrm{g} \mathrm{m}^{-3}$ (Laakso et al., 2003). This episode was also observed in Sweden and Estonia (Niemi et al., 2003).

In mid-March, a ridge of high pressure strengthened over Finland and the weather turned sunny. The nights were cold. A centre of low pressure closed in from southwest and the centre of high pressure moved slowly over to Russia (Fig. 3). At the same time, southerly

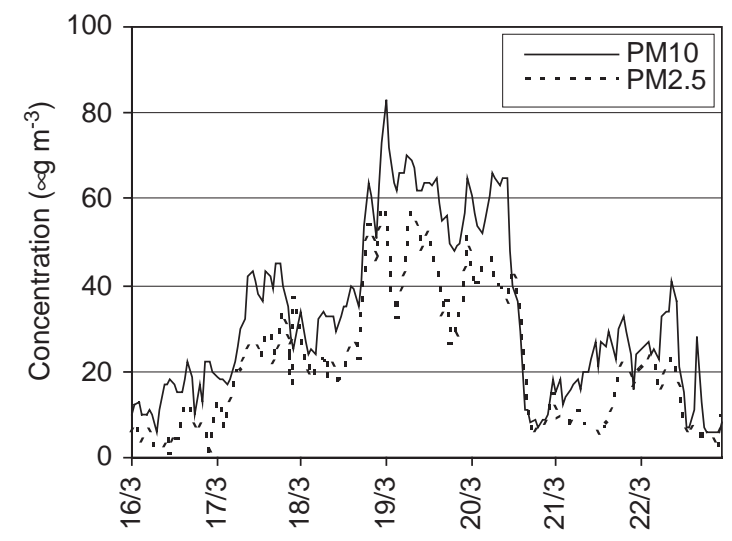

Fig. 2. $\mathrm{PM}_{10}$ and $\mathrm{PM}_{2.5}$ concentrations in Helsinki on March 16-22, 2002. 


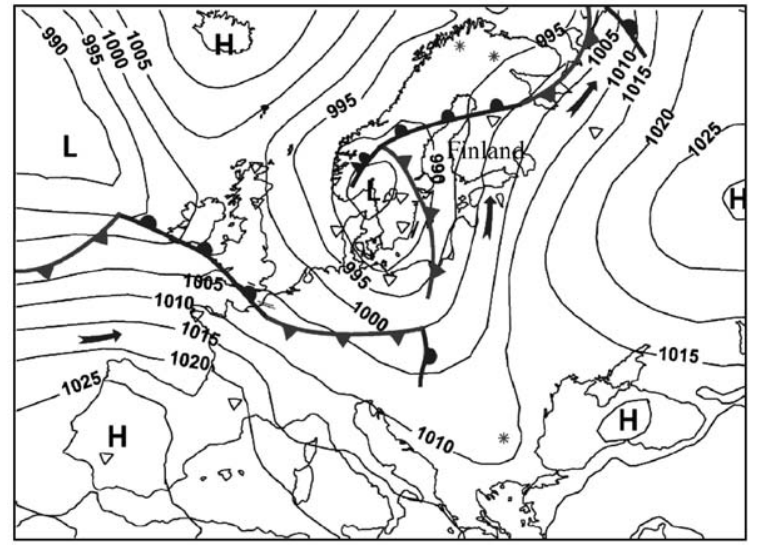

Fig. 3. Weather situation with analysed fronts and isobars in Europe during the strongest stage of the episode (12 UTC March 19, 2002).

airflow increased and very warm air flowed to Finland from the Baltic countries. It rained a little during the night on March 18 and at night the moisture formed a thick fog with occasional drizzle at places. After the fog cleared out, the weather got warmer on March 19, with temperatures of $10^{\circ} \mathrm{C}$ at the southern part of Finland. In Estonia, the temperatures were generally near $15^{\circ} \mathrm{C}$.

The temperature in Helsinki varied during the episode between 0 and $10^{\circ} \mathrm{C}$ and the relative humidity was typically $70-90 \%$. The wind speed varied from 3 to $10 \mathrm{~m} \mathrm{~s}^{-1}$ and the wind direction changed from south west to south east during the episode. Very small showers occurred, but the total rainfall was below $1 \mathrm{~mm}$.

The backward trajectories (http://www.arl.noaa.gov/ ready.html) showed that air masses arrived over Helsinki at the beginning of the episode (March 17) from Russia via the Baltic countries (Estonia, Latvia and Lithuania). Air masses arrived from the Ukraine and Poland during the peak stage of the episode (March 19) passing over Belarus and the Baltic countries (Fig. 4). At the same time, there was a strong agricultural field-burning period in these areas. The largest and most intense fire areas were observed by firemonitoring satellites. Fig. 5 shows the locations of potential fire areas on March 16-19 as presented by the web fire mapper (http://maps.geog.umd.edu).

\subsection{Particle mass and number size distributions}

We compared the strongest period of the episode (March 18-21, 2002) with a reference period (March $8-14$ and $22-28,2002)$ surrounding the episode. Table 1 shows the particle mass and number size fractions at the Hyytiälä measurement station. The size is defined in terms of the particle diameter $\left(D_{\mathrm{p}}\right)$ and the limits for nucleation, Aitken and accumulation modes are also

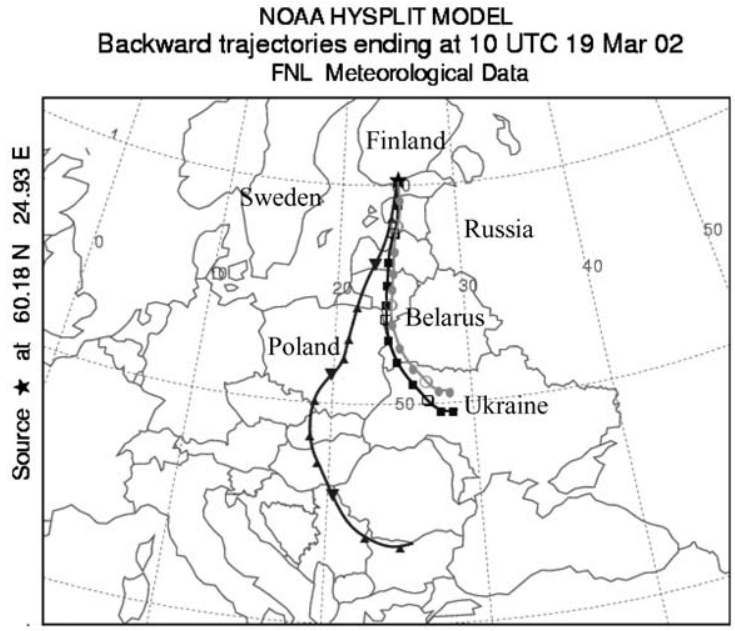

Fig. 4. Trajectories $(72 \mathrm{~h})$ to Helsinki during the strongest stage of the episode (March 19, 2002). Vertical heights at the start were $10 \mathrm{~m}$ (circles), $100 \mathrm{~m}$ (squares) and $500 \mathrm{~m}$ (triangles) above ground level.

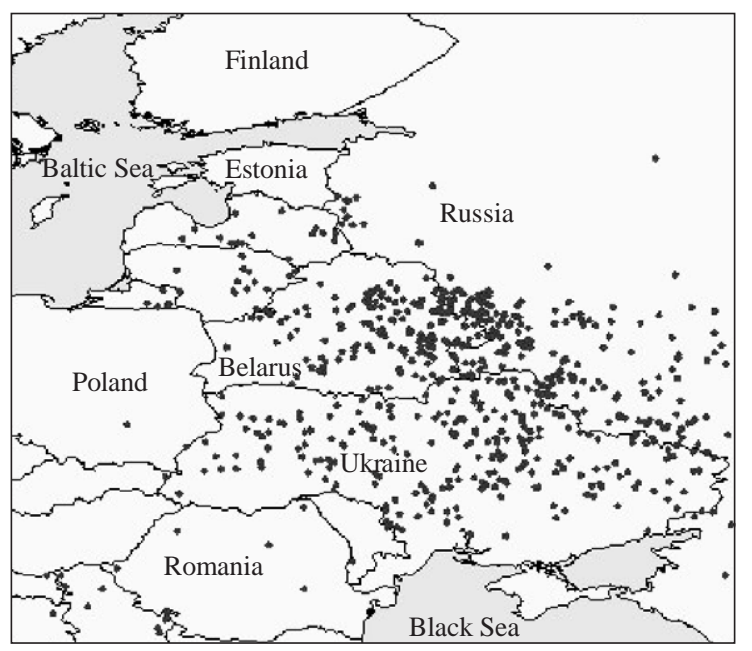

Fig. 5. Terra-MODIS fire detections in Eastern Europe on March 16-19, 2002.

given in the table. Most of the particle mass was in the submicrometre size range during the episode as well as on the reference days. During the episode the particle mass increased by a factor of 4.4 compared with the reference period for size classes $D_{\mathrm{p}}<1 \mu \mathrm{m}\left(\mathrm{PM}_{1}\right)$, $D_{\mathrm{p}}<2.5 \mu \mathrm{m}\left(\mathrm{PM}_{2.5}\right)$ and $D_{\mathrm{p}}<10 \mu \mathrm{m}\left(\mathrm{PM}_{10}\right)$, but above $10 \mu \mathrm{m}$ the concentrations remained at the reference level.

The particle number concentration increased during the episode by a factor of 5.6 in the accumulation mode above $90 \mathrm{~nm}$, decreased slightly (factor of $\frac{2}{3}$ ) in the Aitken mode and decreased strongly (factor of $\frac{1}{6}$ ) in the 
Table 1

Mass and number size fractions in Hyytiälä during the episode and the reference period

\begin{tabular}{|c|c|c|c|c|c|c|c|c|}
\hline & $\begin{array}{l}\mathrm{PM}_{1} \\
\left(\mu \mathrm{g} \mathrm{m}^{-3}\right)\end{array}$ & $\begin{array}{l}\mathrm{PM}_{2.5} \\
\left(\mu \mathrm{g} \mathrm{m}^{-3}\right)\end{array}$ & $\begin{array}{l}\mathrm{PM}_{10} \\
\left(\mu \mathrm{g} \mathrm{m}^{-3}\right)\end{array}$ & $\begin{array}{l}>10 \mu \mathrm{m} \\
\left(\mu \mathrm{g} \mathrm{m}^{-3}\right)\end{array}$ & $\begin{array}{l}\text { Nucl. } \\
(3-25 \mathrm{~nm}) \\
\left(\# \mathrm{~cm}^{-3}\right)\end{array}$ & $\begin{array}{l}\text { Aitken } \\
(25-90 \mathrm{~nm}) \\
\left(\# \mathrm{~cm}^{-3}\right)\end{array}$ & $\begin{array}{l}\text { Accum. } \\
(90-500 \mathrm{~nm}) \\
\left(\# \mathrm{~cm}^{-3}\right)\end{array}$ & $\begin{array}{l}\text { Total } \\
(3-500 \mathrm{~nm}) \\
\left(\# \mathrm{~cm}^{-3}\right)\end{array}$ \\
\hline $\begin{array}{l}\text { Reference days } \\
\text { (March } 8-14 \text { and 22-28, 2002) }\end{array}$ & 3.6 & 4.8 & 5.9 & 0.3 & $\begin{array}{r}1713 \\
1161^{*}\end{array}$ & 1525 & 480 & $\begin{array}{l}3717 \\
3166^{*}\end{array}$ \\
\hline $\begin{array}{l}\text { Episode } \\
\text { (March 18-21, 2002) }\end{array}$ & 15.4 & 22.3 & 24.6 & 0.3 & $\begin{array}{r}273 \\
211^{*}\end{array}$ & 955 & 2703 & $\begin{array}{l}3924 \\
3867^{*}\end{array}$ \\
\hline $\begin{array}{l}\text { Springtime average } \\
\text { (Laakso et al., 2003) }\end{array}$ & 4.4 & 6.4 & 7.4 & - & $810^{*}$ & 1270 & 660 & $2720^{*}$ \\
\hline
\end{tabular}

We also show 3-year (1999-2001) mean springtime values reported by Laakso et al. (2003).

${ }^{*}$ Denotes the concentration calculated with nucleation mode limits $10-25 \mathrm{~nm}$ as in Laakso et al. (2003).

nucleation mode. The disappearance of the smallest particles was expected, since condensation on the abundant larger particles was able to consume all the condensable vapours, and gas-to-particle conversion could not form new particles. If some nucleation mode particles were formed, they also were immediately scavenged by the larger particles.

The evolution of size distributions during the episode days confirmed the fact that hardly any new particles were formed during this time. In general, significantly increased concentrations of particles with diameter between 90 and $500 \mathrm{~nm}$ occurred during the episode, but the total concentration was fairly unaffected. Fig. 6 shows the opposing behaviour of large and small particles. We depicted the ratio of nucleation mode particle concentration to the total concentration $\left(N_{\text {nuc }} /\right.$ $N_{\text {tot }}$ ) between sizes 3 and $500 \mathrm{~nm}$ and the ratio of accumulation mode particle concentration to the total concentration $\left(N_{\text {acc }} / N_{\text {tot }}\right)$. We also show the ratio of accumulation mode concentration to the Aitken mode concentration $\left(N_{\text {acc }} / N_{\text {Ait }}\right)$, but the highest values of this ratio (reaching 6) during the episode were omitted for figure clarity. Aitken mode concentrations normally exceed those of the accumulation mode in Hyytiälä, and high values of $N_{\text {acc }} / N_{\text {Ait }}$ are typical for polluted air masses transported over long distances, since the sources for accumulation mode particles are scarce in the area around Hyytiälä and Aitken mode particles have shorter lifetimes than the accumulation mode particles. The deposition efficiency has a maximum at the Aitken sizes, and the Aitken mode particles also disappear by colliding and sticking to the accumulation mode particles.

Our mass and number concentrations agree with the longer mean springtime values of Laakso et al. (2003), especially when considering that the 3-year means also contain episode-like periods, and thus their higher values for larger particles and lower values for nucleation mode particles compared with our reference period

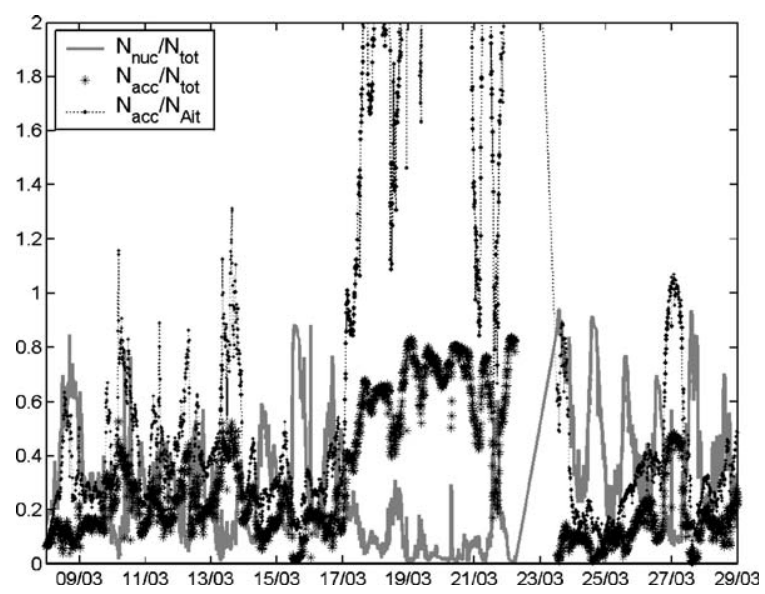

Fig. 6. Selected ratios of nucleation mode (diameter $3-25 \mathrm{~nm}$ ), Aitken mode (25-90 nm), accumulation mode (90-500 nm) and total $(3-500 \mathrm{~nm})$ particle number concentrations in Hyytiälä during the episode on March 17-22, 2002 and surrounding reference periods on March 8-16 and 23-29, 2002. Measurements were done with a twin DMPS system. Accumulation/ Aitken mode ratio attained values near 6 during the episode, but we left values above 2 out of the figure.

are understandable. We also analysed the data from the downtown Helsinki DMPS measurement. Local pollution sources in Helsinki, especially from traffic, blur the picture, but these data support the conclusions drawn from the Hyytiälä experiments.

\subsection{Ion analyses}

Fig. 7 shows the 24-h mean TSP concentrations of sulphate, total nitrate, and total ammonium at the Ähtäri measurement station in March 2002. The concentrations of all these chemical components increased strongly during the episode. Even higher concentrations were measured at Virolahti and Utö, 


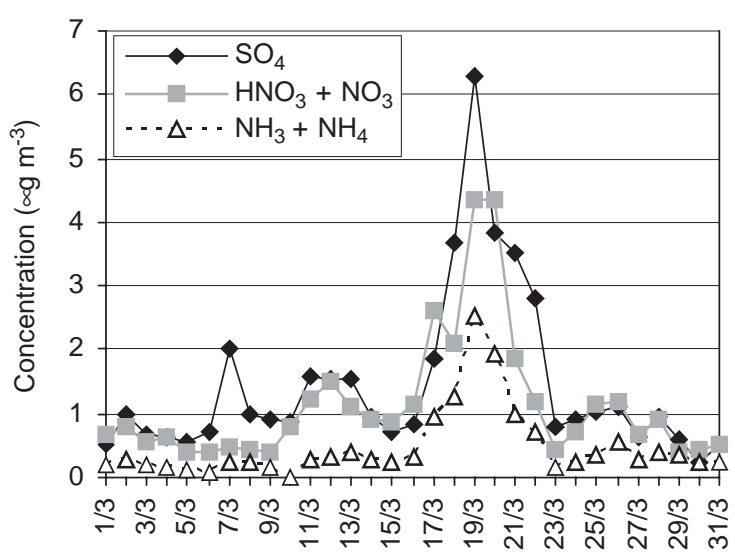

Fig. 7. Daily mean total suspended particle (TSP) concentrations of $\mathrm{SO}_{4}^{2-}$, total nitrate $\left(\mathrm{NO}_{3}^{-}+\mathrm{HNO}_{3}(\mathrm{~g})\right)$, total ammonium $\left(\mathrm{NH}_{4}^{+}+\mathrm{NH}_{3}(\mathrm{~g})\right)$ at $\mathrm{Ähtäri} \mathrm{in} \mathrm{March} \mathrm{2002.} \mathrm{Sample} \mathrm{change} \mathrm{time}$ was at 6 am (UTC).

which are coastal EMEP stations (Fig. 1). The ion sums (total amount) of these chemical components during the episode (March 18-21) were $9.2 \mu \mathrm{g} \mathrm{m}^{-3}$ at Ähtäri, $11.3 \mu \mathrm{g} \mathrm{m}^{-3}$ at Utö and $13.1 \mu \mathrm{g} \mathrm{m}^{-3}$ at Virolahti. These values are 4-5 times higher than those usually observed at these sites in this time of year (Leinonen, 2001).

We estimated the proportions of the above-mentioned ions in the LRT particle mass by comparing the ion concentrations measured at Ähtäri and the particle mass concentrations measured at Hyytiälä, since the latter were not measured at Ähtäri or the other EMEP stations. The results from Ähtäri and Hyytiälä are comparable, since they are located near each other (distance $\sim 90 \mathrm{~km}$ ) and there are no significant anthropogenic emission sources near these sites. Paatero et al. (2001) also determined that the daily concentrations of sulphate, nitrate and ammonium usually were nearly the same at these 2 sites (Pearson correlation coefficients $(R) \sim 0.94)$ during their 1-year study. Since nearly all the particle mass was in the $\mathrm{PM}_{2.5}$ fraction during the episode (March 18-21), we compared the $\mathrm{PM}_{2.5}$ and ion concentrations. The proportions of ions were $19 \%$ for sulphate, $14 \%$ for total nitrate and $8 \%$ for total ammonium, suggesting that about $40 \%$ of the LRT particle mass was composed of these ions.

The estimated proportions of ions during the episode are quite similar compared with long-term measurements at rural background stations in southern Finland. For example, the main $\mathrm{PM}_{2.3}$ components at Luukki, where most of the particle mass is of LRT origin, are sulphate $(25 \%)$, soil $(13 \%)$, nitrate $(11 \%)$, ammonium $(10 \%)$ and unknown matter (37\%) (Ojanen et al., 1998; Pakkanen et al., 2001b). The origins of these ions during the episode are discussed below.

\subsection{Individual particle analyses by SEM/EDX}

The elemental composition of single particles and agglomerates was examined with SEM/EDX from samples collected in the Helsinki metropolitan area during the episode and reference days. The particles were classified into 7 different groups based on the element that was most abundant in each particle: (1) S, (2) $\mathrm{Si}$ or $\mathrm{Al}$, (3) $\mathrm{Ca}$, (4) $\mathrm{Fe}$, (5) $\mathrm{Na}$ or $\mathrm{Cl}$, (6) $\mathrm{K}$ and (7) low-Z. Particles in the low-Z class contained only elements with an atomic number lower than $11(\mathrm{Na})$, such as $\mathrm{C}, \mathrm{N}$ and $\mathrm{O}$, which could not be analysed quantitatively with the SEM/EDX device we used. We also classified particles using hierarchical cluster analysis, but the elemental compositions of the LRT particles during the episode proved to be so homogenous that more specific classification was not necessary here.

The abundance of S-rich particles and agglomerates was extraordinarily high during the episode (Fig. 8); e.g. the $\mathrm{PM}_{2.5}$ samples of the urban background station at Kallio contained $88-92 \%$ S-rich particles during the episode, but only $7-11 \%$ during the reference days. The proportion of S-rich particles was very high, even in the $\mathrm{PM}_{2.5}$ sample of the urban traffic station at Vallila and also in the $\mathrm{PM}_{10}$ sample of the rural background station at Luukki.

In addition to $\mathrm{S}$, S-rich particles and agglomerates contained large amounts of $\mathrm{C}$ and $\mathrm{O}$ as well as some $\mathrm{Na}$, $\mathrm{K}$ and $\mathrm{Si}$ (Fig. 9). The presence of $\mathrm{C}$ was confirmed by analysing some S-rich particles directly on the gold coated surface of (C-free) fibreglass filters. Most of the individual S-rich particles were small (geometric diameter $<1 \mu \mathrm{m}$ ), but they usually formed larger agglomerates. A substantial part of the agglomeration probably occurred during particle sampling and sample preparation for the SEM/EDX analyses.

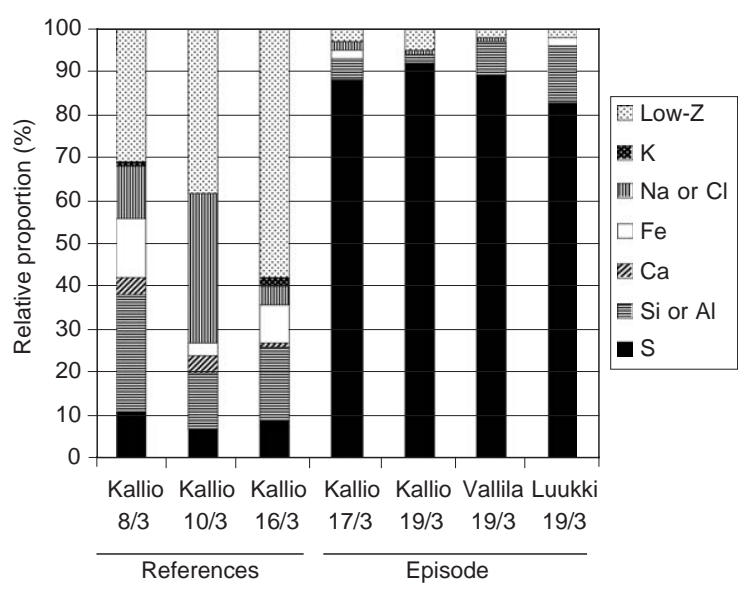

Fig. 8. Abundance of particle groups (\%) in the reference and episode samples from different measurement stations in the Helsinki metropolitan area in March 2002. 


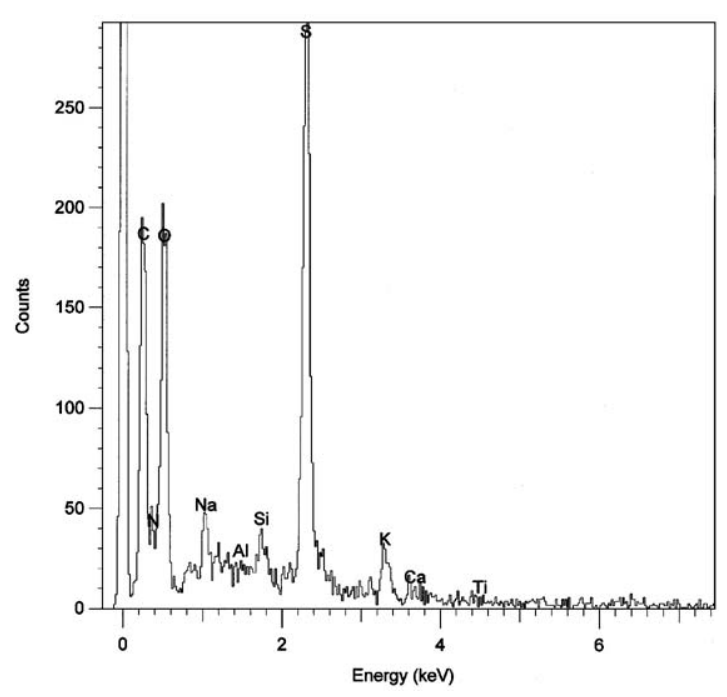

Fig. 9. A SEM/EDX spectrum of a typical particle type observed during the episode of March 2002.

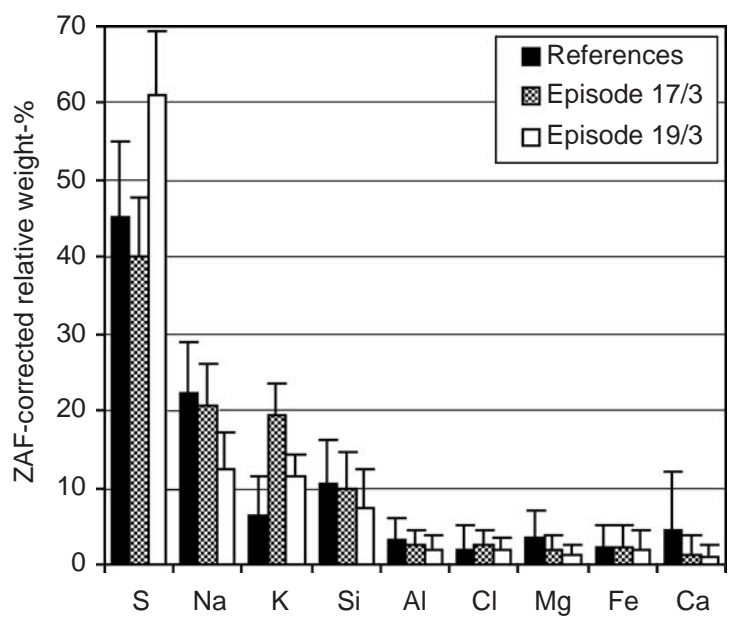

Fig. 10. Average weight percentages of selected elements in Srich particles during the reference days and the episode. Error bars represent standard deviation (SD). Results are semiquantitative and weight percentages are normalized to $100 \%$.

We compared the elemental ratios of S-rich particles in the $\mathrm{PM}_{2.5}$ samples collected at the Kallio station at different times. Fig. 10 shows the relative weight percentages of analysed elements in S-rich particles and agglomerates during the reference days, and at the beginning (March 17) and the peak stage (March 19) of the episode. These results are only semiquantitative but they are well suited for the comparison of different samples. The relative weight percentage of $\mathrm{K}$ was much higher at the beginning of the episode $(19.3 \%)$ than during the reference days $(6.3 \%)$. The relative abundance of S was clearly higher at the peak stage of the episode $(61.2 \%)$ than during the reference days $(45.2 \%)$. An increase in $\mathrm{S}$ leads to a relative decrease in other elements, but despite that the relative weight percentage of $\mathrm{K}$ remained still somewhat higher at the peak stage of the episode $(11.4 \%)$ than during the reference days. All previously mentioned differences are statistically significant $(p<0.001$, Mann-Whitney $U$-test, SPSS10 program).

One of the main chemical components in S-rich particles and agglomerates was doubtless sulphate. High increase in sulphate (as well as in nitrate and ammonium) concentrations during the episode was already confirmed in IC analyses in the previous chapter. However, the SEM/EDX analyses showed that there was an unusually high proportion of $\mathrm{K}$ in S-rich particles during the episode, especially at the beginning of the episode. This is a clear indication of emissions from biomass burning, because $\mathrm{K}$ in the fine size fraction is well known as a good tracer of biomassburning aerosols (Andreae, 1983; Andreae et al., 1998). The trajectories and fire area map (see Figs. 4 and 5) indicate that during the episode the major part of the biomass-burning emissions originated from large-scale agricultural field burning in the Baltic countries, Belarus, Ukraine and Russia. Part of the biomassburning emissions may also have originated from other biomass burning sources (e.g. wood combustion) in these areas (Liousse et al., 1996).

Organic and black carbon are major components of particulate matter from biomass burning (Andreae and Merlet, 2001). Emissions of many gaseous compounds (e.g. $\mathrm{NO}_{x}, \mathrm{NH}_{3}$ and to a lesser extent also $\mathrm{SO}_{2}$ ), which form secondary particulate masses during transport, are also quite high. Thus, a remarkable fraction of the $\mathrm{C}$ and secondary ion mass $\left(\mathrm{NO}_{3}^{-}, \mathrm{NH}_{4}^{+}, \mathrm{SO}_{4}^{2-}\right)$ in the LRT particles clearly originated from agricultural field burning during the episode. Other important chemical components from biomass burning include $\mathrm{K}$ salts. Potassium chloride $(\mathrm{KCl})$ occurs in young smoke, whereas increased amounts of potassium sulphate $\left(\mathrm{K}_{2} \mathrm{SO}_{4}\right)$ and potassium nitrate $\left(\mathrm{KNO}_{3}\right)$ are present in aged smoke. This is due to the rapid substitution of chloride by sulphate and nitrate during the aging of smoke (Liu et al., 2000; Li et al., 2003). S-rich particles from the episode contained very little $\mathrm{Cl}$ as expected, because $\mathrm{Cl}$ had already been depleted during the LRT. $\mathrm{S}$-rich particles also contained some $\mathrm{Na}$ and $\mathrm{Si}$, which may have originated partly from biomass burning but also from many other sources (e.g. marine aerosols, fossil fuel burning and refuse incineration) during transport (Watson et al., 2001; Ooki et al., 2002).

The $\mathrm{S} / \mathrm{K}$ ratios of particles were used as indicators to describe the rate of accumulation of $\mathrm{S}$ compounds in biomass-burning aerosols during transport (Gaudichet 
et al., 1995; Liu et al., 2000; Li et al., 2003). The median $\mathrm{S} / \mathrm{K}$ ratios of S-rich particles were 2.1 at the beginning of the episode, 5.2 at the peak stage of the episode and 8.9 during the reference days. The values occurring at the beginning of the episode were very high compared with the $\mathrm{S} / \mathrm{K}$ ratios measured near the biomass burning sources (S/K-ratio 0.1: Gaudichet et al., 1995; Turn et al., 1997; Christensen et al., 1998; Hedberg et al., 2002), but quite similar to the typical values measured from hazes farther distant from the burning areas (K/S-ratio 0.4-2.3: Andreae et al., 1988; Artaxo et al., 1994; Pereira et al., 1996). However, during the peak stage of the episode, the $\mathrm{S} / \mathrm{K}$ ratio was clearly higher compared to that occurring during the beginning of the episode and other previously mentioned studies. The relative weight percentage of $\mathrm{S}$ was also very high compared with that occurring during the reference days (see Fig. 10). This indicates that large amounts of sulphatecontaining compounds (e.g. $\mathrm{H}_{2} \mathrm{SO}_{4},\left(\mathrm{NH}_{4}\right) \mathrm{HSO}_{4}$ or $\left.\left(\mathrm{NH}_{4}\right)_{2} \mathrm{SO}_{4}\right)$ were present in the LRT particulate mass during the peak stage of the episode. The trajectories showed that the air masses arrived during the peak stage of the episode from areas where $\mathrm{S}$ emissions from fossil fuel burning are especially high (EMEP, 2001), but from more eastern and less polluted areas at the beginning of the episode. We conclude that at the beginning of the episode the major fraction of the LRT particle mass originated from biomass burning, whereas during the peak stage of the episode the influx from fossil fuel emissions increased.

\section{Summary and conclusions}

A strong LRT PM 2.5 episode occurred from March 17-22, 2002 in large areas of Finland. Most of the LRT particle mass was in the submicrometre size fraction. The mass of the submicrometre particles increased by a factor of 4.4 during the episode at the rural background station in Hyytiälä. The number concentrations of $90-500 \mathrm{~nm}$ particles increased by a factor of 5.6, but the concentrations of particles smaller than $90 \mathrm{~nm}$ were reduced. The smallest particles are produced by gas-toparticle conversion, which was suppressed during the episode due to the vapour uptake of LRT particles. These results show how strongly the LRT of particles affects not only the fine particle mass but also the number size distributions of submicron particles. This emphasizes the need to investigate and monitor both the number and mass concentrations of particles to obtain a true picture of particle sources and composition in different situations.

The IC measurements show that the concentrations of sulphate, total nitrate, and total ammonium increased during the episode, and that the total amount of these chemical compounds was about 4-5 times higher than that usually encountered. The proportion of these compounds from the $\mathrm{PM}_{2.5}$ mass was estimated to be about $40 \%$, which is quite typical for LRT particle masses in Finland. Individual particle analyses with SEM/EDX showed that the amount of S-rich particles increased strongly during the episode compared with those observed during the reference days. The relative weight percentage of $\mathrm{K}$ was unusually high in S-rich particles during the episode. This is a clear indication of emissions from biomass burning, because $\mathrm{K}$ is a good tracer of biomass-burning aerosols. The median $\mathrm{S} / \mathrm{K}$ ratios of S-rich particles were 2.1 at the beginning of the episode, 5.2 at the peak stage of the episode and 8.9 during the reference days. These values suggest that the proportion of biomass-burning aerosols was especially high in the LRT particle mass at the beginning of the episode. From information available in the trajectories and fire maps, we conclude that the main source of biomass-burning aerosols during the episode was the large-scale agricultural field burning in the regions of the Baltic countries, Belarus, Ukraine and Russia. Higher S/ $\mathrm{K}$ ratios during the peak stage of the episode indicate increased mixing of sulphate-containing species in the biomass-burning emissions. This was obviously due to the higher proportion of fossil fuel burning emissions in the LRT particle mass, since the air masses arrived from the more polluted areas of Europe during the peak stage the episode.

Springtime agricultural field burning is a traditional cultivation technique, especially in Eastern Europe. Hundreds of burning areas can be seen every spring in these regions by fire-monitoring satellites (http://firemaps.geog.umd.edu). Our results suggest that largescale field burning may substantially affect PM2.5 concentration under unfavourable meteorological conditions, even at the distances of over $1000 \mathrm{~km}$ from the burning areas. However, similar field fire episodes only rarely reach Finland due to springtime rains and winds. The LRT biomass burning $\mathrm{PM}_{2.5}$ episodes observed in Finland have usually been caused by large forest fires in Russia and other Eastern European countries (Niemi et al., 2003).

\section{Acknowledgements}

We acknowledge the Helsinki University Environmental Research Centre and Helsinki Metropolitan Area Council for funding this study. The Cooperative Institute for Research in Environmental Sciences, University of Colorado at Boulder, is gratefully acknowledged for a Visiting Fellowship (HT). We would also like to thank our colleagues at the following institutes for their collaboration during the work: Pasi Aalto, Veijo Hiltunen and Lauri Laakso (Division of Atmospheric Sciences, University of Helsinki), Risto 
Hillamo, Jussi Paatero and Timo Salmi (Finnish Meteorological Institute), Kari Lounatmaa (Helsinki University of Technology) and Kaarle Kupiainen and Mika Räisänen (Nordic Envicon Ltd.). The authors gratefully acknowledge the National Oceanographic and Atmospheric Administration (NOAA) Air Resources Laboratory (ARL) for provision of the HYSPLIT transport and dispersion model (http://www.arl.noaa.gov/ ready.html) used in this publication.

\section{References}

Andreae, M.O., 1983. Soot carbon and excess fine potassium: long-range transport of combustion derived aerosols. Science 220, 1148-1151.

Andreae, M.O., Merlet, P., 2001. Emission of trace gases and aerosols from biomass burning. Global Biogeochemical Cycles 15, 955-966.

Andreae, M.O., Browell, E.V., Garstang, M., Gregory, G.L., Harriss, R.C., Hill, G.F., Jacob, D.J., Pereira, M.C., Sachse, G.W., Setzer, A.W., Dias, P.L.S., Talbot, R.W., Torres, A.L., Wofsy, S.C., 1988. Biomass-burning emissions and associated haze layers over Amazonia. Journal of Geophysical Research-Atmospheres 93, 1509-1527.

Andreae, M.O., Andreae, T.W., Annegarn, H., Beer, J., Cachier, H., le Canut, P., Elbert, W., Maenhaut, W., Salma, I., Wienhold, F.G., Zenker, T., 1998. Airborne studies of aerosol emissions from savanna fires in southern Africa: 2. Aerosol chemical composition. Journal of Geophysical Research-Atmospheres 103, 32119-32128.

Artaxo, P., Gerab, F., Yamasoe, M.A., Martins, J.V., 1994. Fine mode aerosol composition at 3 long-term atmospheric monitoring sites in the Amazon Basin. Journal of Geophysical Research-Atmospheres 99, 22857-22868.

Breed, C.A., Arocena, J.M., Sutherland, D., 2002. Possible sources of $\mathrm{PM}_{10}$ in Prince George (Canada) as revealed by morphology and in situ chemical composition of particulate. Atmospheric Environment 36, 1721-1731.

Christensen, K.A., Stenholm, M., Livbjerg, H., 1998. The formation of submicron aerosol particles, $\mathrm{HCl}$ and $\mathrm{SO}_{2}$ in straw-fired boilers. Journal of Aerosol Science 29, $421-444$.

Dockery, D.W., Pope, C.A., 1994. Acute respiratory effects of particulate air-pollution. Annual Review of Public Health $15,107-132$.

Draxler, R.R., Rolph, G.D., 2003. HYSPLIT (HYbrid SingleParticle Lagrangian Integrated Trajectory). Model access via NOAA ARL READY Website (http://www.arl. noaa.gov/ready/hysplit4.html). NOAA Air Resources Laboratory, Silver Spring, MD.

EMEP, 2001. Transboundary acidification and eutrophication and ground level ozone in Europe. Joint CIAM \& CCC \& MSC-W report. EMEP Summary Report 1/2001. URL http://www.emep.int/reports/EMEP_Report_1_2001.pdf

EMEP, 2002. Transboundary particulate matter in Europe: Status Report 2002. EMEP Report 5/2002. URL http:// www.nilu.no/projects/ccc/reports/emep5-2002.pdf

Gao, Y., Anderson, J.R., 2001. Characteristics of Chinese aerosols determined by individual-particle analysis. Journal of Geophysical Research-Atmospheres 106 (D16), 18037-18045 (12000JD900725).

Gaudichet, A., Echalar, F., Chatenet, B., Quisefit, J.P., Malingre, G., Cachier, H., Buatmenard, P., Artaxo, P., Maenhaut, W., 1995. Trace-elements in tropical African savanna biomass burning aerosols. Journal of Atmospheric Chemistry 22, 19-39.

Hedberg, E., Kristensson, A., Ohlsson, M., Johansson, C., Johansson, P.-A., Swietlicki, E., Vesely, V., Wideqvist, U., Westerholm, R., 2002. Chemical and physical characterization of emissions from birch wood combustion in a wood stove. Atmospheric Environment 36, 4823-4837.

Justice, C.O., Giglio, L., Korontzi, S., Owens, J., Morisette, J.T., Roy, D., Descloitres, J., Alleaume, S., Petitcolin, F., Kaufman, Y., 2002. The MODIS fire products. Remote Sensing of Environment 83, 244-262.

Karppinen, A., Härkönen, J., Kukkonen, J., Aarnio, P., Koskentalo, T., 2004. Statistical model for assessing the portion of fine particulate matter transported regionally and long range to urban air. Scandinavian Journal of Work, Environment \& Health, in press.

Kerminen, V.M., Ojanen, C., Pakkanen, T., Hillamo, R., Aurela, M., Meriläinen, J., 2000. Low-molecular-weight dicarboxylic acids in an urban and rural atmosphere. Journal of Aerosol Science 31, 349-362.

Kiehl, J.T., Rodhe, H., 1995. Modeling geographical and seasonal forcing due to aerosols. In: Charlson, R.J., Heintzenberg, J. (Eds.), Aerosol Forcing of Climate. Wiley, New York, pp. 281-296.

Kupiainen, K., Tervahattu, H., Räisänen, M., 2003. Experimental studies about the impact of traction sand on urban road dust composition. Science of the Total Environment 308, 175-184.

Laakso, L., Hussein, T., Aarnio, P., Komppula, M., Hiltunen, V., Viisanen, Y., Kulmala, M., 2003. Diurnal and annual characteristics of particle mass and number concentrations in urban, rural and Arctic environments in Finland. Atmospheric Environment 37, 2629-2641.

Laden, F., Neas, L.M., Dockery, D.W., Schwartz, J., 2000. Association of fine particulate matter from different sources with daily mortality in six US cities. Environmental Health Perspectives 108, 941-947.

Leinonen, L. (Ed.), 2001. Air quality measurements 2000. Finnish Meteorological Institute, Helsinki.

Li, J., Posfai, M., Hobbs, P.V., Buseck, P.R., 2003. Individual aerosol particles from biomass burning in southern Africa: 2, Compositions and aging of inorganic particles. Journal of Geophysical Research-Atmospheres 108 (D13), 8484 doi: 8410.1029/2002JD002310.

Liousse, C., Penner, J.E., Chuang, C., Walton, J.J., Eddleman, H., Cachier, H., 1996. A global three-dimensional model study of carbonaceous aerosols. Journal of Geophysical Research-Atmospheres 101 (D14), 19411-19432 (19495JD03426).

Liu, X.D., Van Espen, P., Adams, F., Cafmeyer, J., Maenhaut, W., 2000. Biomass burning in southern Africa: individual particle characterization of atmospheric aerosols and savanna fire samples. Journal of Atmospheric Chemistry $36,135-155$.

Niemi, J., Tervahattu, H., Aarnio, P., 2002. Long-range transport episodes of aerosols in Helsinki, March and 
August 2002. In: Vehkamäki, H., Vesala, T. (Eds.), Report Series in Aerosol Science. Aerosolitutkimusseura ry., Helsinki, pp. 30-33.

Niemi, J., Tervahattu, H., Koskentalo, T., Sillanpää, M., Hillamo, R., Kulmala, M., Vehkämaki, H., 2003. Studies on the long-range transport episodes of particles in Finland in March and August 2002 (in Finnish with an English abstract). Pääkaupunkiseudun julkaisusarja B 2003:10. Helsinki Metropolitan Area Council, Helsinki. ISBN 951-798-541-X URL http://www.ytv.fi/ilmanl/aineisto/ kaukokulkeumaepisodi_2003.pdf

Ojanen, C., Pakkanen, T., Aurela, M., Mäkelä, T., Meriläinen, J., Hillamo, R., Aarnio, P., Koskentalo, T., Hämekoski, K., Rantanen, L., Lappi, M., 1998. Size distribution, composition and sources of inhalable particles in the Helsinki metropolitan area (in Finnish with an abstract in English). Pääkaupunkiseudun julkaisusarja C 7. Helsinki Metropolitan Area Council (YTV), Helsinki.

Ooki, A., Uematsu, M., Miura, K., Nakae, S., 2002. Sources of sodium in atmospheric fine particles. Atmospheric Environment 36, 4367-4374.

Paatero, J., Valkama, I., Makkonen, U., Laurén, M., Salminen, K., Raittila, J., Viisanen, Y., 2001. Inorganic components of the ground-level air and meteorological parameters at Hyytiälä, Finland during the BIOFOR project 1998-1999. Reports No. 2001:3. Finnish Meteorological Institute, Helsinki.

Pakkanen, T.A., Kerminen, V.-M., Korhonen, C.H., Hillamo, R.E., Aarnio, P., Koskentalo, T., Maenhaut, W., 2001 a. Urban and rural ultrafine $\left(\mathrm{PM}_{0.1}\right)$ particles in the Helsinki area. Atmospheric Environment 35, 4593-4607.

Pakkanen, T.A., Loukkola, K., Korhonen, C.H., Aurela, M., Mäkelä, T., Hillamo, R.E., Aarnio, P., Koskentalo, T., Kousa, A., Maenhaut, W., 2001b. Sources and chemical composition of atmospheric fine and coarse particles in the Helsinki area. Atmospheric Environment 35, 5381-5391.

Paoletti, L., De Berardis, B., Diociaiuti, M., 2002. Physicochemical characterisation of the inhalable particulate matter (PM10) in an urban area: an analysis of the seasonal trend. Science of the Total Environment 292, 265-275.

Pereira, E.B., Setzer, A.W., Gerab, F., Artaxo, P.E., Pereira, M.C., Monroe, G., 1996. Airborne measurements of aerosols from burning biomass in Brazil related to the TRACE a experiment. Journal of Geophysical ResearchAtmospheres 101, 23983-23992.
Pope, C.A., Burnett, R.T., Thun, M.J., Calle, E.E., Krewski, D., Ito, K., Thurston, G.D., 2002. Lung cancer, cardiopulmonary mortality, and long-term exposure to fine particulate air pollution. Jama-Journal of the American Medical Association 287, 1132-1141.

Ruuskanen, J., Tuch, T., Ten Brink, H., Peters, A., Khlystov, A., Mirme, A., Kos, G.P.A., Brunekreef, B., Wichmann, H.E., Buzorius, G., 2001. Concentrations of ultrafine, fine and $\mathrm{PM}_{2.5}$ particles in three European cities. Atmospheric Environment 35, 3729-3738.

Tervahattu, H., Hartonen, K., Kerminen, V.M., Kupiainen, K., Aarnio, P., Koskentalo, T., Tuck, A.F., Vaida, V., 2002. New evidence of an organic layer on marine aerosols. Journal of Geophysical Research-Atmospheres 107 (D7), 4053 doi:4010.1029/2000JD000282.

Turn, S.Q., Jenkins, B.M., Chow, J.C., Pritchett, L.C., Campbell, D., Cahill, T., Whalen, S.A., 1997. Elemental characterization of particulate matter emitted from biomass burning: wind tunnel derived source profiles for herbaceous and wood fuels. Journal of Geophysical Research-Atmospheres 102, 3683-3699.

Vallius, M., Lanki, T., Tiittanen, P., Koistinen, K., Ruuskanen, J., Pekkanen, J., 2003. Source apportionment of urban ambient $\mathrm{PM}_{2.5}$ in two successive measurement campaigns in Helsinki, Finland. Atmospheric Environment 37, 615-623.

Vesala, T., Haataja, J., Aalto, P., Altimir, N., Buzorius, G., Garam, E., Hämeri, K., Ilvesniemi, H., Jokinen, V., Keronen, P., Lahti, T., Markkanen, T., Mäkelä, J.M., Nikinmaa, E., Palmroth, S., Palva, L., Pohja, T., Pumpanen, J., Rannik, Ü., Siivola, E., Ylitalo, H., Hari, P., Kulmala, M., 1998. Long-term field measurements of atmosphere-surface interactions in boreal forest ecology, micrometeorology, aerosol physics and atmospheric chemistry. Trends in Heat, Mass and Momentum Transfers 4, $17-36$.

Watson, J.G., Chow, J.C., Houck, J.E., 2001. PM2.5 chemical source profiles for vehicle exhaust, vegetative burning, geological material, and coal burning in Northwestern Colorado during 1995. Chemosphere 43, 1141-1151.

WHO, 2002. World health report. Reducing risks, promoting healthy life. World Health Organization, Geneva.

WHO, 2003. Health aspects of air pollution with particulate matter, ozone and nitrogen dioxide. Working group report, 13-15 January 2003. World Health Organization, Bonn. URL http://www.who.dk/document/e79097.pdf 